Article

\title{
What Solutions for Waste Management? Issues of Flows and Governance Exemplified by the Łódź Agglomeration (Poland)
}

\author{
Damian Mazurek*(D) and Konrad Czapiewski (D) \\ Institute of Geography and Spatial Organization, Polish Academy of Sciences, 00-818 Warsaw, Poland; \\ konrad@twarda.pan.pl \\ * Correspondence: d.mazurek@twarda.pan.pl; Tel.: +48-226978780
}

Citation: Mazurek, D.; Czapiewski,

K. What Solutions for Waste

Management? Issues of Flows and Governance Exemplified by the Łódź Agglomeration (Poland). Energies 2021, 14, 3366. https://doi.org/ $10.3390 /$ en14123366

Academic Editor: Idiano D’Adamo

Received: 7 May 2021

Accepted: 7 June 2021

Published: 8 June 2021

Publisher's Note: MDPI stays neutral with regard to jurisdictional claims in published maps and institutional affiliations.

Copyright: (c) 2021 by the authors. Licensee MDPI, Basel, Switzerland. This article is an open access article distributed under the terms and conditions of the Creative Commons Attribution (CC BY) license (https:// creativecommons.org/licenses/by/ $4.0 /)$.

\begin{abstract}
This article seeks to propose a waste-management model based on qualitative and quantitative research. Specifically, an analysis of the flow of municipal waste was carried out, with the case involved being that of the biodegradable waste generated in households of Poland's Łódź Metropoli$\tan$ Area, which is heterogeneous from the points of view of both settlement structure and land use. The analysis of flows of waste then served an evaluation of the system of waste management in the study area, while also representing an important input into a process of identification of problems and possible solutions via so-called PULL ("Peri-Urban Living Lab") workshop methodology. Indeed, the research detailed here was participatory throughout (from the stages of problem identification through to conclusion-drawing). All of these stages to the work were kept cohesive through the use of an advanced tool allowing for both analysis of the given area and the devising of strategies by which circular economy could be developed. Specifically, GDSE (GeoDesign Decision Support Environment) programming — devised within the framework of the REPAiR Project—offered opportunities for flows of different kinds of materials and raw materials across space to be identified. It also served in the implementation of Eco-innovative solutions (EIS), as were developed jointly in cooperation with participants of the PULL workshops. The article offers a synthetic presentation of the results of different stages to the research, along with a synthesis relating to the waste-management context, with particular account taken of the development of the circular economy.
\end{abstract}

Keywords: waste management; circular economy; GeoDesign; governance; Łódź Metropolitan Area

\section{Introduction}

The matter and phenomenon of the growing amounts of wastes being generated by human beings initiated the development of research into new kinds of technology, management and planning. Waste management links up with a series of processes associated with the planned receipt of wastes, the setting-up of routes for vehicles to travel, the selection of processing technologies, the locating of infrastructures (containers, shelters, waste-processing installations, storage areas and incinerators), strategic planning to ensure the necessary future processing capacity of installations, the timetabling of deliveries and the dividing up of a country, region and local-authority area to meet the needs of management [1].

A particularly problematic issue here can prove to be the organised collection or receipt of wastes - as well as their subsequent management in all its manifestations-in areas that are diverse from the point of view of geographical conditions [2]. Matters of key significance in each such situation will include the function that an area serves, its settlement structure and demographic conditioning-as all related or subordinated to the given unit of local or regional government responsible for such matters. These kinds of factors are proving to be highly dynamic, and-bearing in mind the need for long-term planning of new investment and new developments in waste managementthese processes and the subsequent management activity are obviously of more and more 
significance. Indeed, waste management is looking like a particular challenge for the burgeoning cities in the developing countries, whose generation of wastes is mushrooming, along with attendant servicing costs that can prove impossible for those involved to bear [3]. In Poland, new residential developments mainly appearing in the suburban zones of cities are located in areas characterised by a lack of continuous built-up area, with this taken to imply higher costs of public services [4]. It is only now that work is being done to shape processes by which we may identify influencing factors-at the stage at which principles for the shaping of a waste-management system are being developed in areas that are themselves still under development [3].

A review of the literature has revealed a fairly rich spectrum of studies addressing waste-management issues. However, as the analyses are often of global in nature, translation down to the local dimension often proves difficult. It is not entirely clear what European Union (EU) climate policy or national plans for a circular economy will mean for local policy relating to development, what processes will be triggered, and what the consequences for local communities are likely to be. While some of the analyses deal with governance, flow analysis or the transport of waste in a given region, searches for references to territory treated as an organism diverse in almost every respect, functioning under specific rules and represented by specific stakeholder groups are found to be in vain. The problems on the local scale are more complex than macroeconomic data might suggest. Obviously, a comprehensive approach to research carries certain risks, so at the outset it should be noted that the study presented in this paper does not address all aspects of waste management. Passing references to processing technologies that appear in this text forman element of the expert studies under the REPAiR project and are not the subject of this study. Instead, the analysis carried out by reference to the example of the Łódź agglomeration revealed and offered additional opportunities for analysis in the contexts of the cognition, spatial planning and implementation of eco-innovative solutions on a local scale. It was therefore this aspect that emerged as most interesting to the authors, especially in view of the way the waste management system in Poland has been developing dynamically in recent years, even as technological development and changes in the behaviour of society have also been taking place. This leaves it necessary for a model framework to be devised so that the municipal waste-management system can be described using both workshop potential and the potential of human beings as stakeholders and hence future beneficiaries of solutions.

Against that background, this article has sought to set out and explain the relationships pertaining to a triad of linkages involving: the generation and flow of wastes in an agglomeration $\rightarrow$ perceptions relating to (and the management of) the process(es) by which wastes are collected and utilised $\rightarrow$ possibilities for public-participation methods to be applied on the basis of the use of ICT (Information and Communication Technologies). The work detailed here therefore pursues further certain matters raised within the REPAiRProject framework (Horizon 2020). The motivation for taking up the issue of waste management was a geographical context associated with the directions taken by flows of biodegradable wastes generated in the internally differentiated area of central Poland's Łódź agglomeration. According to Czapiewski et al. [5], biodegradable wastes constitute around $30 \%$ of all municipal wastes and may have various kinds of secondary use made of them.

However, Poland has so far made only limited use of the potential biodegradable waste has to offer, with this seen to reflect the difficulties encountered with their management, given unfavourable conditions of a legal, social, infrastructural and economic nature. It has been in this connection that the authors have sought to do research using modern methods and tools-i.e., PULL (Peri-Urban Living Labs) and GDSE (the GeoDesignDecision Support Environment) - with a view to waste-management problems being identified, and strategies developed, in a participatory and synergistic manner. This article's authors refer to results from the above Project, while posing questions on how Project conclusions in the waste-management context may be synthesised, on the basis of a now-detailed 
understanding of the directions taken by a region's flows of wastes. The resultant effort has indeed supplied conclusions regarding a model for the management of municipal wastes that refers to methods of planning in line with actual spatial flows of wastes, as well as possibilities and means for these to be managed. The basis throughout has been the GeoDesign research concept [6]. The Łódź Metropolitan Area was chosen for study in the face of a scientific postulate that analyses of aspects of development of the circular economy are still lacking at the level of such smaller spatial units as the agglomeration or city. This may be seen in the way most literature apparently focuses on much larger units-mainly because more-detailed data at other levels is lacking [7].

The paper is divided into 7 main parts. Following their Introduction, the authors devote space to a review of the broad spectrum of available literature and to a characterisation of the waste-management system in Poland as seen from the legislative perspective. The research methods used are then described, before the paper's main part offers a description of the results of flow analysis, as well as the participatory and social methods used. Two last parts are then devoted to Discussion, with the authors relating the results of their research to the subject literature, and Conclusions - in which they reflect on the potential of the methods presented, as well as the results of the social and spatial research results carried out.

\section{Waste Management-A Theoretical Overview}

The literature can offer us many studies devoted to selected aspects of waste management. When it comes to the spatial aspects, researchers have used GIS (Geographic Information Systems) to focus on optimised transport (e.g., [8-10]), decision systems for location of infrastructure [11], methods of such analysis [12], multi-criteria a spatial analysis [13,14], GIS network optimization models [15], as well as analysing possible locations for waste-treatment and processing installations using GIS decision models on the case study of small region including several gminas [16], assessing amounts of waste generated $[17,18]$ and analysing flows of wastes by way of MFA (Material Flow Analyses, e.g., $[19,20])$. Additionally conducted were comparative analyses of systems of waste management in Poland and other EU Member States [21], analyses of amounts of wastes generated through the year in different cities of Eastern Europe [22], comparisons of the waste-management systems present in European states [23] and regional analyses on the whole-country scale and in the context of the relationship between waste management and environmental pollution [24]. Many publications have referred to organisational (or institutional) aspects, and to systems assisting with decision-making (e.g., [11,25-29]), including as regards regional-level planning relating to harmful wastes [30] and the role of stakeholders in planning [31]. Beyond that, a great deal of work has been devoted to analysing the waste-management systems of different states, like Portugal [32], South Africa [28] and Uganda [33]. Additionally raised widely is the aspect of waste-processing technologies, not least in the context of environmental impact, costs and social aspects, like LCA [34,35], based on Leontief's input-output theory [36], and strictly referred to the aspects of various technologies [37-39], inter alia focused on chosen ones [40].

A period of dynamic development of work on waste management came in the 1970s-1990s [41]. However, this was as conceived broadly, with the associated circular economy mainly being addressed on a macrostructural scale. Detailed analyses of flows of wastes only began to be carried out once the technological possibilities for doing that had been enhanced. For example, in recent years, many models relating to transport economics, means of management and influences on the environment have emerged. Given the multiaspect nature of the problem, the complexity of settlement structures and the dynamic nature of demographic processes, multi-criteria models have proved especially suitable.

A comprehensive study devoted to models of waste management was developed by Ghiani et al. [1]. Those authors drew a distinction between location models that were single-period, multi-period or multi-purpose, integrating economic and social components and with an unknown. Where objectives of research are concerned a distinction is drawn 
between 3 categories of model entailing: life-cycle assessment, cost-benefit evaluations of system functioning and facilitated decision-making [41]. MSWMs (Municipal Solid Waste Management Models) have been divided into 2 groups [26]. The first group relates to social factors in decision-making processes, while the second concerns public participation at different stages, even as the most important role is seen to be played at the level of recognition of the problem and education. MSWMs can also be divided in line with the method used. To be distinguished among the latter are CAM (the Consensus Analysis Model), MCDM (Multi-criteria Decision Making), MOP (Multi-objective Programming) and LCA (or Life Cycle Assessment). All of these can serve as instruments assisting with strategic planning. They supply valuable information in regard to flows, the possibilities for wastes to be reused and the consequences of different planned solutions.

The practice of waste management is dependent on several factors and is not confined to the determination of ways of designating and directing wastes, or the effort to meet the standards set out in law, e.g., in matters of what share of all wastes go for recycling. The essence of strategic planning is to foresee processes capable of influencing how a system operates. In turn, amounts of municipal wastes generated are seen to depend on population, among other things, and that also differs from one area to another and over time. Dyson and Chang [42] devised a model taking account of system dynamics and making the results dependent on changes of these kinds. Their study area was the thendynamically developing city of San Antonio. Indeed, dynamic processes of urbanisation and suburbanisation demand that solutions be implemented appropriately in advance, hence waste management being more difficult in areas like San Antonio than where change is either absent or limited. The building of new waste-processing installations can take between 1 and 4 years [1], and in this connection the models anticipating change and forecasting potential consequences play a major role in the strategic planning of new developments and system management. A strategy should take account of the rate of change in the given area and be based on skill in adapting infrastructure to future need. In further stages, planning should focus in on the devising of optimal paths, choice of contractors, location of new developments and their processing capacity, possibilities for wastes to be processed, the introduction of new technologies and so on.

Appropriate management is a basic element in the process of transformation from a linear to a circular economy [43]. Research into a waste-free economy was carried out in Poland as early as in the 1980s [44]. Today, the term is applied widely in the context of the development of waste management [45-47]. As the circular economy remains a major challenge for weakly-developed countries [48], these first take steps that focus on appropriate organisation and the devising of management models.In Poland, research on the circular economy was carried out in relation to the extractive-industry sector by Smol et al. [49]. The present study extends such literature devoted to the circular economy, and also brings in social and spatial aspects of research in the context of the utilisation of municipal wastes.

\section{Waste Management and the Polish Legal System}

Waste is a by-product of human activity, introduced into the environment in small or large quantities, including as the primal product, but unsuitable in the place and time at which it was generated. In accordance with Poland's Wastes Act of 12 December 2012, [50] waste is "any substance or object, the holder of which disposes of, intends to dispose of or is obliged to dispose of". Waste is therefore any material, raw material or final product, which is not employed or deployed, has no designated purpose and is not used for a specific purpose [51]. Waste is then considered to be any substance or object which the holder disposes of, intends to dispose of or is obliged to dispose of. On the other hand, the (initial) waste producer is understood as any person whose activity or existence results in the generation of waste, while a waste producer more generally can also be anyone who performs pre-treatment, mixing or other activities bringing about a change in the nature or composition of waste. 
Despite advanced research on the repeat use of wastes as raw materials, the degree of sorting of wastes remained very low in Poland as recently as in 2011, due to a lack of relevant regulation and management instruments. However, as the issue of waste generation is a matter of national and indeed global importance [52], the introduction of appropriate legislative solutions had to be viewed as a just a matter of time. Indeed, core changes in the law obliging citizens to sort their waste were made in 2012, by virtue of the Wastes Act, inter alia a consequence of Directive 2008/98/EC [53] being adopted by the EP. Under the latter, Member States are obliged to depart steadily from the linear economy in the direction of a circular one. The Polish legislator had among its relevant objectives a raised effectiveness of the waste-management system. Making reference to the EU guidelines, the Polish regulations introduced a list of processes working to reduce amounts of wastes generated, and to ensure that the use made of them is as efficient as possible. The Act includes the following goals arranged in order in the waste hierarchy, i.e., (1) the prevention of waste-generation, (2) preparation for reuse, (3) recycling, (4) other recovery processes and (5) disposal.

The system of waste management in Poland comprises 5 basic elements with various relationships pertaining between them (Figure 1). The legislator has imposed an obligation that local authorities (i.e., the units of administration at gmina level) take responsibility and pursue tasks where the delivery and management of wastes in their areas are concerned. In this context, as in others, gminas may associate together via agreements that help them implement tasks conferred upon them. The collection of wastes from those who generate them is one such task, as is the management and utilisation of the wastes in question in a such a way that the percentage by mass that is subject to recycling is raised as high as possible. Such a process usually involves the commissioning of private-sector enterprises to perform tasks in respect of the receipt and management of wastes. As a 2007 communique from the Polish Chamber of Waste Management [54] makes clear, such enterprises prove very much more effective in helping local authorities meet the standards imposed upon them. This is why local authorities find themselves engaging in tendering for service provision, while also requiring inhabitants to pay a fee in line with a declared number of members of a given household. The way in which ordinary people are to sort wastes is also now dictated to them by local government, while further obligations involve the running of a localauthority register with data on amounts of waste utilised and processed at different installations, as well as relevant reporting upwards to the Office of the Marshal of the given Polish voivodeship [43].

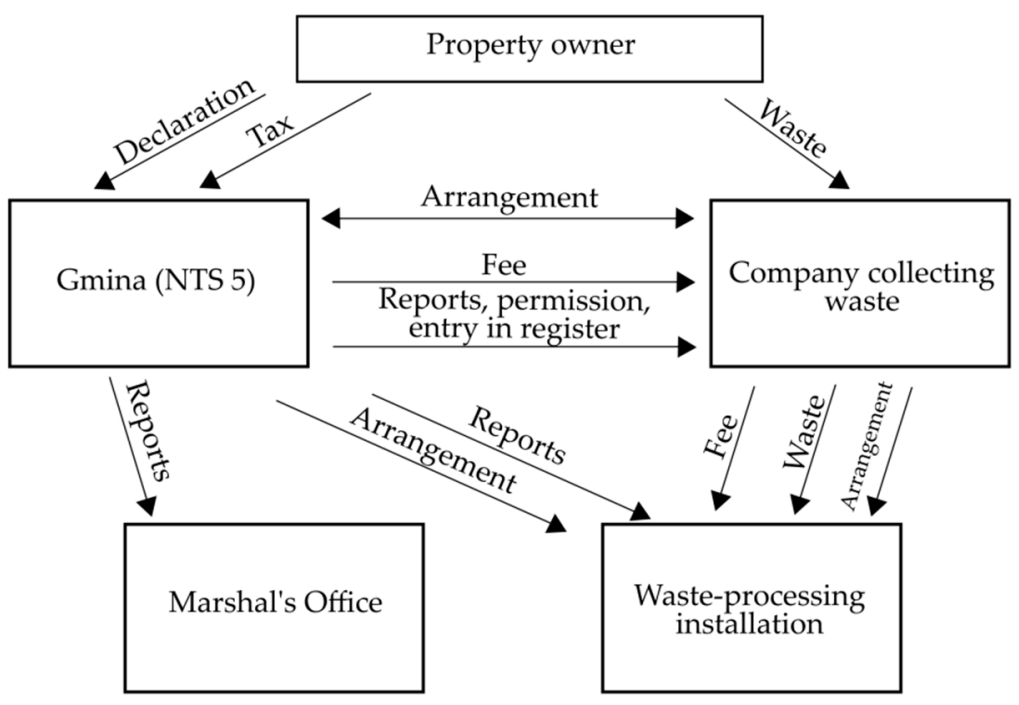

Figure 1. The system of waste management in Poland Source: authors' own elaboration. 
Local government is responsible, not only for organising the collection of municipal waste, but also for other aspects of waste management also related to processes of investment. The most important tasks here include the development and application of regulations relating to cleanliness and order, the determination of rates payable in respect of municipal waste management, the construction, operation and maintenance of installations and equipment for waste recovery and disposal, and the pursuit of tendering procedures in respect of the collection and management of waste [55]. On the other hand, the responsibilities of regional authorities (acting at the level of the Polish voivodeship) include the development of the Provincial Waste Management Plan and indication of regional installations for processing municipal waste.

The waste-management system in Poland imposes a division of the country's territory into 123 waste-management regions, under which modern facilities established are Regional Municipal Waste Treatment Plants (RIPOK) whose construction is assumed to develop an effective waste-management system. In line with the principle of the division into regions, the Plants are responsible for receiving and dealing with specific groups of waste from the region of generation. To ensure constant inflow via the waste stream, a basic principle of waste management followed is the so-called "proximity principle" highlighting the need for wastes to be treated and/or disposed of in reasonable proximity to their point of generation. This means that the waste is processed at the place where it is produced and, if this is impossible, is transferred to the nearest place where it can be processed. Indeed, it is forbidden for waste to be transported beyond the region of origin.

In Poland, until recently, the most common form of waste disposal was simply dumping at landfills. This was not in line with the principle requiring that as little waste as possible be dealt with in this way [56]. However, recent years have brought very dynamic changes in the field of waste management. This is confirmed primarily by the introduction of new regulations and legal provisions adapting waste management to regulations in force throughout the EU Member States. The amount of scientific research and documentation carried out in this field has also increased, with this being the background for a diagnosis of contemporary changes in waste management resulting from new regulations [57-59]. The context of the study was expanded to include, among other things, geographical considerations [60]. All studies emphasise a major increase in the role played by local authorities and regions when it comes to the management and disposal of municipal waste. Waste management has also become a good business occupation related to the collection, sorting and storage of waste, and various forms of use in the generation of renewable energy.

Following the introduction of the new Waste Management Act in 2013 [50], a number of indicators illustrating society's approach to waste and changes concerning the treatment of wastes collected have shown improvement (Figure 2). Above all, the change involving the local-authority takeover of responsibility in the field of waste collection has ensured that all inhabitants are now the subjects of compulsory municipal waste collection, while in 2012 this indicator for Poland as a whole amounted to 80\%. Concurrently, the number of illegal waste dumps-i.e., places not intended for landfill—has decreased significantly (from almost 4400 in 2009 to 1900 in 2019), while the area covered is only one-third as high as it was. At the same time, educational campaigns and financial incentives have led to a considerable increase in the share of waste collected selectively "at source", i.e., in households-from a few per cent a decade ago to over 31\% today. With the introduction of obligatory collection of household waste, their participation in total mass increased from around $70 \%$ in the pre-implementation period (prior to 2013) to $85 \%$ today. Moreover, the methods for the further collection and processing of gathered municipal waste have also changed significantly. As recently as in 2005 , almost all collected mixed municipal waste was deposited in landfills, whereas today that share is down to $40 \%$. 


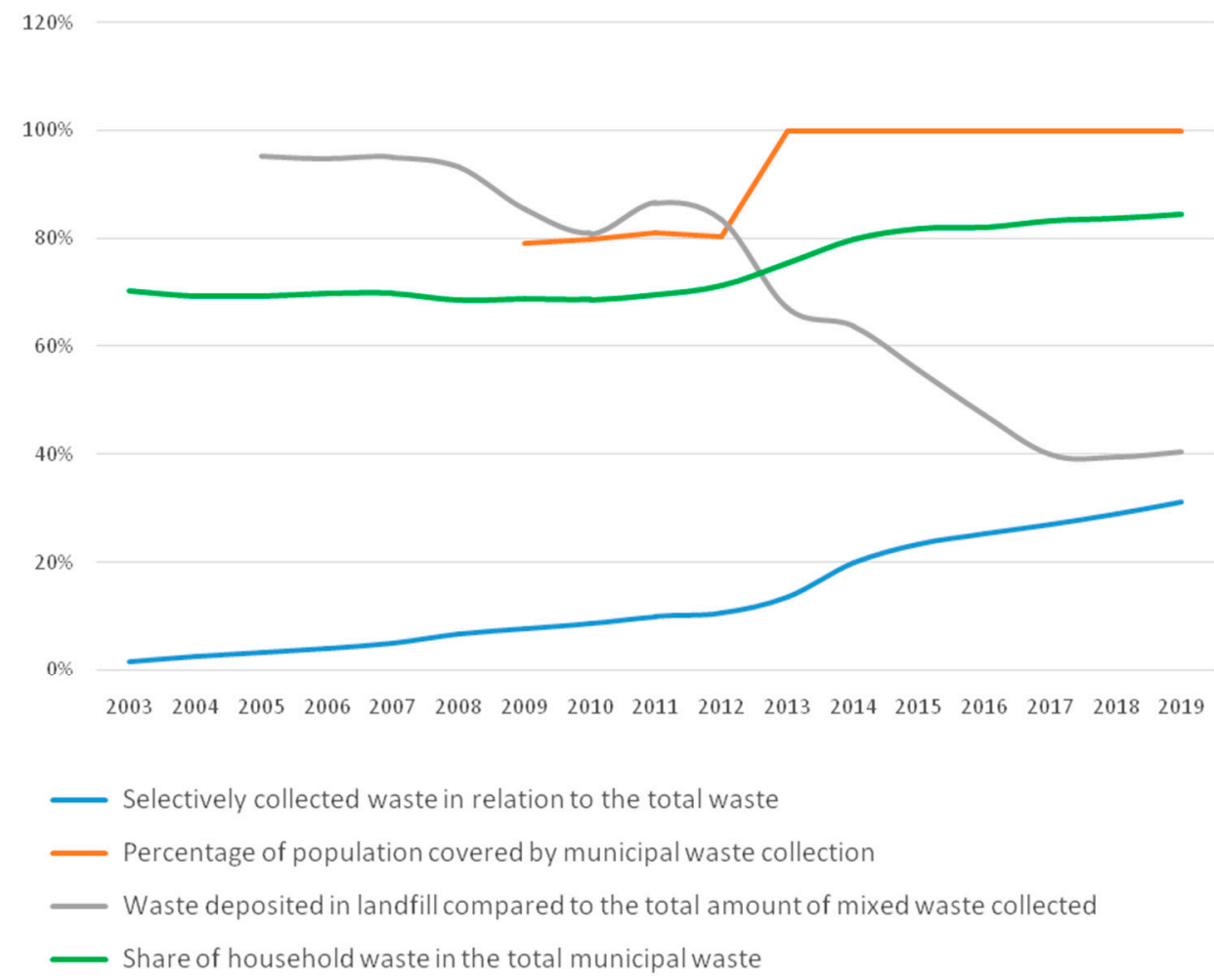

Figure 2. Changes in values for selected indicators of waste management in Poland Source: authors' own elaboration.

\section{Materials and Methods}

\subsection{The Study Area}

The work was carried out in the September 2016-December 2020 period, under the international REPAiR Project (denoting Resource Management in Peri-urban Areas: Going Beyond Urban Metabolism) — as financed by the European Commission within the framework of the Horizon 2020Programme (http:/ / h2020repair.eu/, access: 9 November 2020). In its theoretical aspects, analysis relevant to this was pursued using the GeoDesign concept (after Steinitz [6]). In turn, the empirical side involved the examples supplied by the 6 different metropolitan areas of Amsterdam, Hamburg, Pécs, Ghent, Naples and Łódź [61]. It is obviously the situation of the last of these cities that has been elaborated on here, in line with the results of research carried out.

The Łódź Metropolitan Area (in Polish: Łódzki Obszar Metropolitalny, abbreviated as $€ O M$ ) is located in central Poland and comprises the main communication hub on the northsouth (Gdańsk-Upper Silesia) and east-west (Warsaw-Poznań) axes (Figure 3). The ŁOM is characterised by a generally lowland landscape of slightly varied relief. This area has been very much transformed by human activity, mainly with 19th-century industrialisation and accompanying processes of urbanisation and the development of the communication network. The ŁOM encompasses five county-level poviats-as NUTS 4 administrative units (i.e., the city of Łódź, Łódź East, Brzeziny, Zgierz and Pabianice)—and has a total area of $2500 \mathrm{~km}^{2}$. It in turn consists of 28 of Poland's gminas as NUTS 5 (local) administrative units, inhabited by over 1.1 million people — of which 706,000 are residents of the city of Łódź itself. For a number of years Łódź was the most important textile-industry centre in Poland. Being key among the employees of this sector, women migrated massively to the city, very much exceeding men. Following the collapse of the centrally-planned economic system of the communist era, the majority of state-owned textile factories in Łódź were liquidated. As a consequence, the last two decades have witnessed a decline in the number of inhabitants of Łódź, albeit with a concurrent increase in the number of people living in the city's vicinity. 


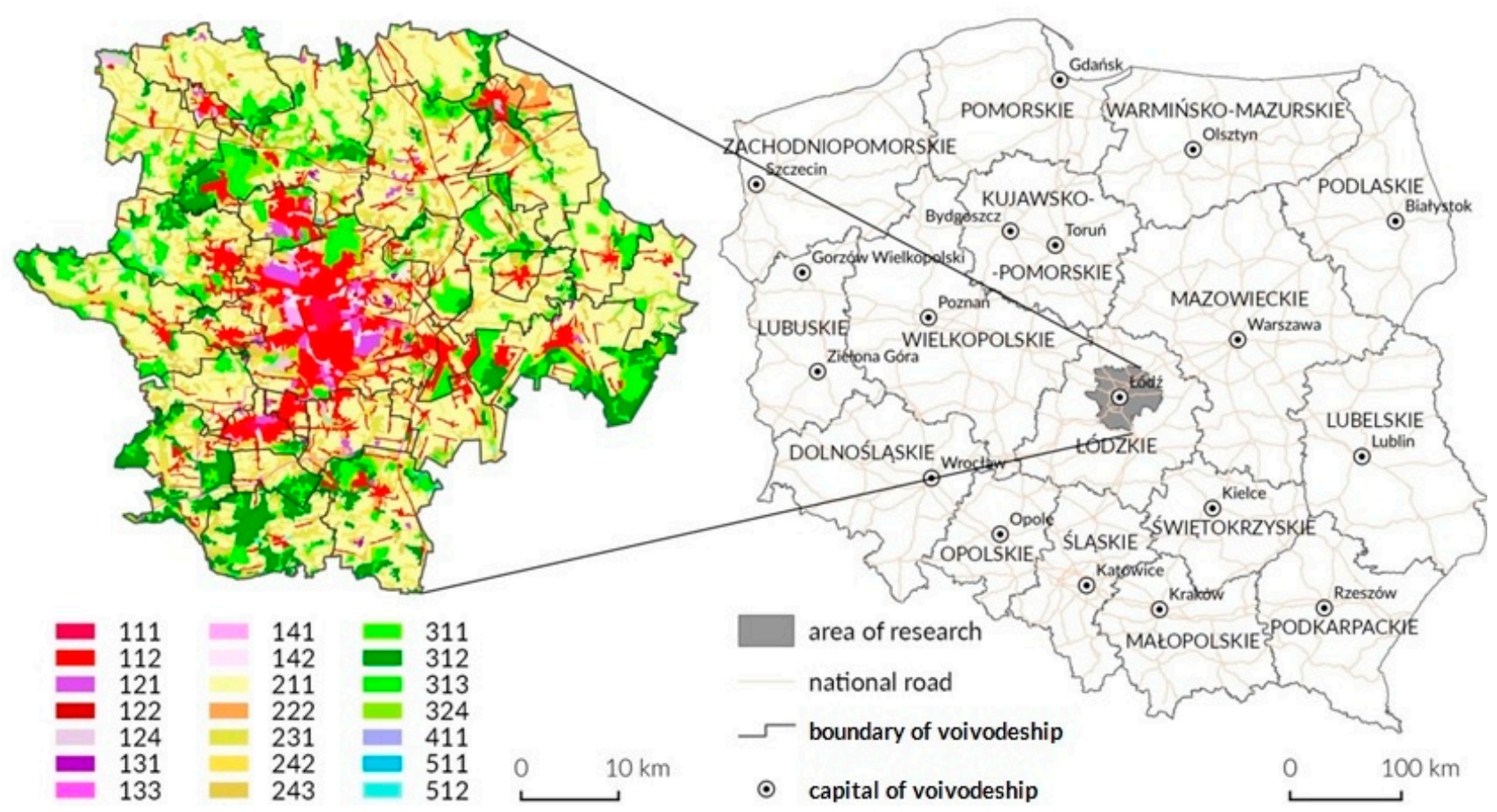

Figure 3. Łódź Metropolitan Area-land use (Corine Land Cover 2018) and location.1.1.1. Continuous urban fabric, 1.1.2. Discontinuous urban fabric, 1.2.1. Industrial or commercial units, 1.2.2. Road and rail networks and associated land, 1.2.4. Airports, 1.3.1. Mineral extraction sites, 1.3.3. Construction sites, 1.4.1. Green urban areas, 1.4.2. Sport and leisure facilities, 2.1.1. Non-irrigated arable land, 2.2.2. Fruit trees and berry plantations, 2.3.1. Pastures, 2.4.2. Complex cultivation patterns, 2.4.3. Land principally occupied by agriculture, with significant areas of natural vegetation, 3.1.1. Broadleaved forest, 3.1.2. Coniferous forest, 3.1.3. Mixed forest, 3.2.4. Transitional woodland-scrub, 4.1.1. Inland marshes, 5.1.1. Watercourses, 5.1.2. Water bodies.Source: authors' own elaboration based on data from GIOŚ (the Chief Inspectorate of Environmental Protection)—Corine Land Cover 2018 (http:/ / clc.gios.gov.pl access: 5 November 2020)

\subsection{Methods}

\subsubsection{Material Flow Analysis}

A number of different data were obtained to allow the system of waste management in the Łódź Metropolitan Area to be diagnosed. Specifically, these were used in analysis of quantities of wastes generated, flows of wastesand installations involved in the processing of wastes and means by which wastes are managed and utilised. The main sources of this kind of information were local authority reports on wastes, in our case in relation to 2016. The elaboration of maps first involved the preparation of a matrix-based database able to encapsulate the relationships between different elements of the waste-management system. Specifically, these elements were households (represented as localities in the base), the installations that handle and process wastes, and the points at which the selective collection of different municipal wastes is engaged in (known by the abbreviation PSZOK in Polish). Data were structure in line with origin-i.e., the source of the wastes generated, to which it was also possible to ascribe an overall mass in tonnes per year, and destination-i.e., place to which wastes are dispatched, as well as the processes to which they become subject having arrived at the given installation. Matrix data were plugged into Quantum GIS programming, with a view to its generating hub lines. These could then be presented with the aid of ribbon cartodiagrams. Processes were in turn presented on circular cartodiagrams.

\subsubsection{Peri-Urban Living Labs}

Our research also made use of two methods of social research, of which the first related to the so-called Peri-Urban Living Labs-at which groups of REPAiR Project stakeholders met several times. Representatives of different groups-local-government institutions, 
NGOs, waste companies, environmental institutions and others-in fact met regularly throughout the Project, participating in discussions that were able to flesh out the research topic, interpret the results obtained and ultimately engage in the testing of solutions arrived at.

\subsubsection{In-Depth Interviews}

A second method involved the interviews with key stakeholders run in summer 2017. All of these were face-to-face and in person. The majority of the semi-structured interviews lasted around an hour and were followed by the filling-in of a questionnaire of eleven main questions. Almost all interview data collected were audio-recorded, before being described, analysed and summarised in transcripts allowing findings to be compared. The interviews were run with Mayors of gminas located within Łódź Metropolitan Area, a Director from the Ministry of Development, and people responsible for waste management and environmental protection.

\subsubsection{The GeoDesign Decision Support Environment}

A further research instrument was the GDSE (GeoDesign Decision Support Environment) application developed under the REPAiR Project framework and making possible the development of spatial planning strategies involving flowsof wastes and based around innovation in regard totechnologies, processes, methods of management and other methods indicated by experts (though in their capacity as participants in PULL research). By allowing stakeholders develop strategies in a fully interactive way it was possible to achieve efficient development of solutions emerging in a participatory fashion that allowed the aforementioned (statistical, spatial-analysis and social-analysis) methods be triangulated.

It was thanks to the possibility of work being done online that experts were simultaneously able to develop a joint strategy; while it was thanks to the opportunity to divide potential beneficiaries into groups that sets of strategies were (also via GDSE) made subject to real-time comparative analysis. This provided an opportunity not available earlier for rapid and comprehensive development of strategies based on data verified substantively (on amounts of wastes, directions assumed by flows, types of actors and generators of wastes and firms involved in their collection and processing), and then fed into the base of the application. Such a strategy comprises: expert (or stakeholder) indication of objectives, eco-innovative solutions (EIS, i.e., one EIS or a compilation of many), modification of EIS indicators by a group of experts, the typifying of actors or groups of actors that the strategy will concern and the delimitation by a group of experts of the area(s) in which the given strategy is to be implemented. The outcomes are strategies (or a single strategy) containing compiled results and consequences (by way of simulation) of the introduction of eco-innovative solutions-as presented in figures, Sankey diagrams, flow mapsand comparative compilations of results obtained and changes involving indicators adopted for strategy evaluation.

\section{Results}

\subsection{Flow Analysis for Waste Materials}

In 2016, municipal waste from the agglomeration was collected by 82 installations located in 13 voivodeships of Poland. About $99 \%$ by mass of the municipal waste mass produced in the Łódź agglomeration was collected by installations operating in the field of waste collection within Łódzkie Voivodeship. The remaining 1\% of all municipal waste mass produced in the agglomeration was collected by installations located outside the voivodeship.

As of 2016, non-biodegradable municipal waste (Figure 4) was utilised by 70 installations. About $99 \%$ by mass of non-biodegradable municipal waste was managed by installations operating within Łódzkie Voivodeship. A majority (54.8\%) of waste of this type was utilised by installations operating within the area of the Łódź agglomeration. 
Non-biodegradable waste is mainly treated by dismantling, sorting, crushing, compacting, granulation, drying, crushing, conditioning, repacking, separation, blending or mixing.

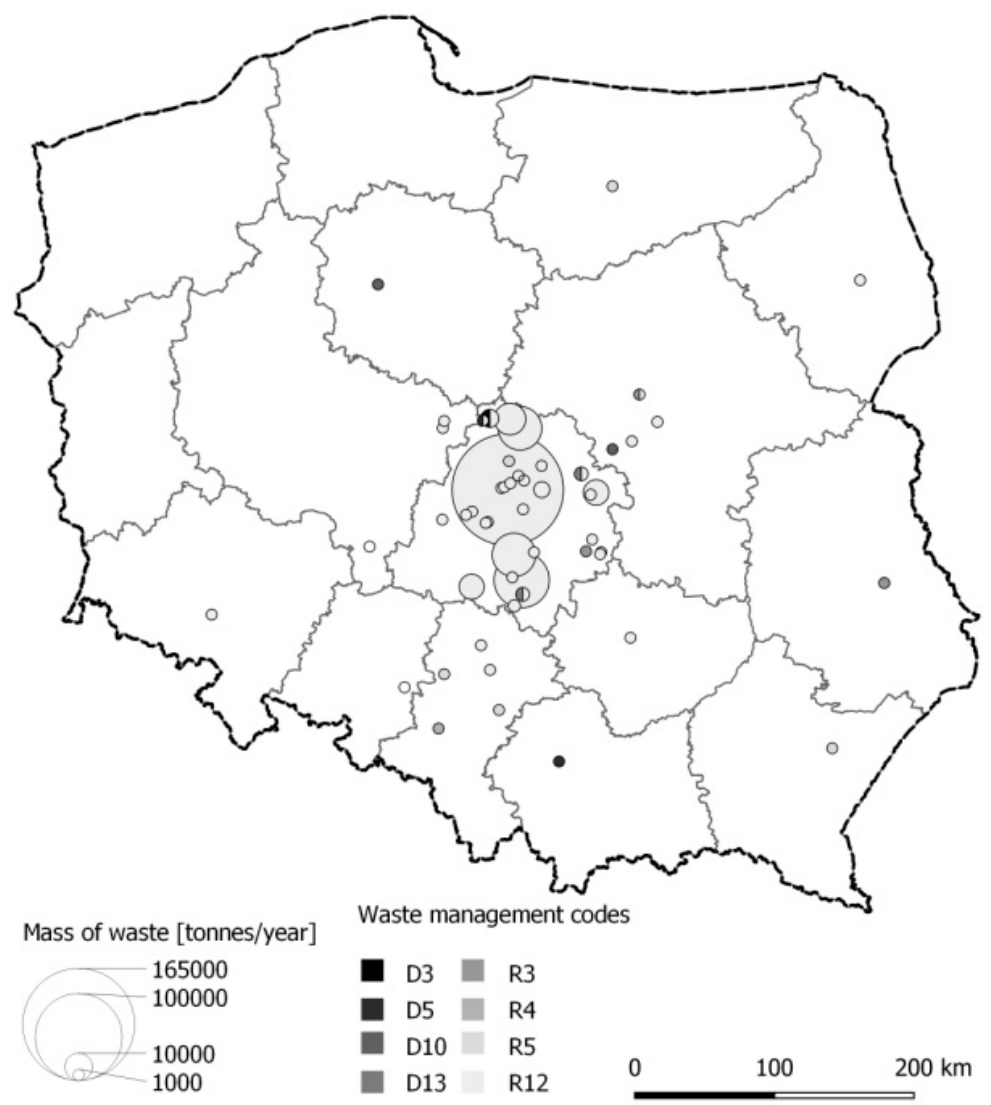

Figure 4. Mass of non-biodegradable municipal waste collected from the Łódź Metropolitan Area and treated by individual installations, by form of waste. D3-Deep injection, D5-Engineered landfill, D10-Incineration on land, D13-Blending or mixing prior to submission to any of the operations numbered D1 to D12, R3-Organic substance recycling/reclamation, R4-Metal recycling/reclamation, R5-Inorganic substance recycling/reclamation, R12-Exchange of waste for submission to any of the operations numbered R1 to R11. Source: author's own study based on data from communal reports for 2016.

As of 2016, biodegradable municipal waste (Figure 5) was managed by 31 installations. About $99 \%$ of it by mass was utilised by installations operating within Łódzkie Voivodeship. About $38.3 \%$ of this type of waste is managed by installations operating in the Łódź agglomeration. Biodegradable waste is mainly treated by way of the recycling of wastepaper and board; the reprocessing and recycling of plastic waste; the composting of biowaste and green waste; and the fermentation of biodegradable waste for biogas production (biogas plants).

Biodegradable wastes originating in the Łódź Metropolitan Area are managed within Łódź voivodeship. This is in line with the Wastes Act, which indeed provides that wastes should be utilised in the same voivodeship as the one in which they were generated. The requirement seems to be fulfilled in relation to biodegradable wastes specifically, as well as more generally. Moreover, there has been designation of RGOKs (regions managing communal wastes and a kind of auxiliary unit). In fact, different parts of the Metropolitan Area now belong to 3 of these Waste Management Regions, and $79 \%$ of the mass of biodegradable wastes generated in the gminas making up the Area are now dealt with by them. The remaining $21 \%$ is subject to longer-distance transport to installations located in other regions. This is the situation as depicted in the map in Figure 6. 


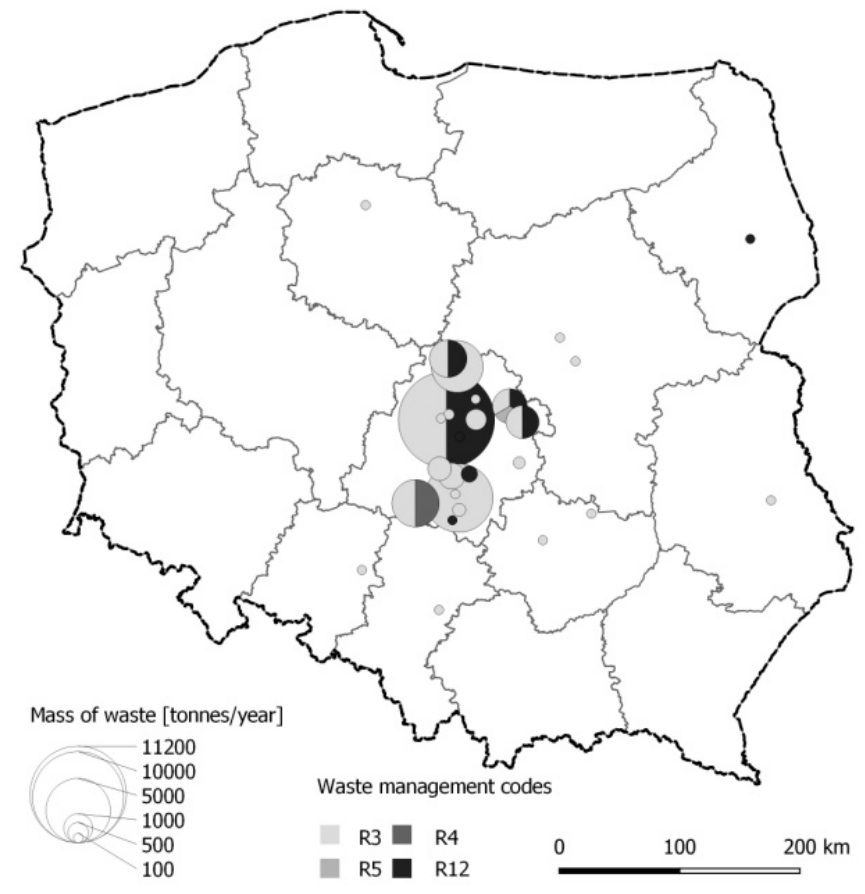

Figure 5. Mass of biodegradable municipal waste collected from the Łódź Metropolitan Area and treated by individual installations, by forms of waste. R3-Organic substance recycling/reclamation, R4-Metal recycling/reclamation, R5-Inorganic substance recycling/reclamation, R12-Exchange of waste for submission to any of the operations numbered R1 to R11. Source: author's own study based on data from communal reports for 2016.

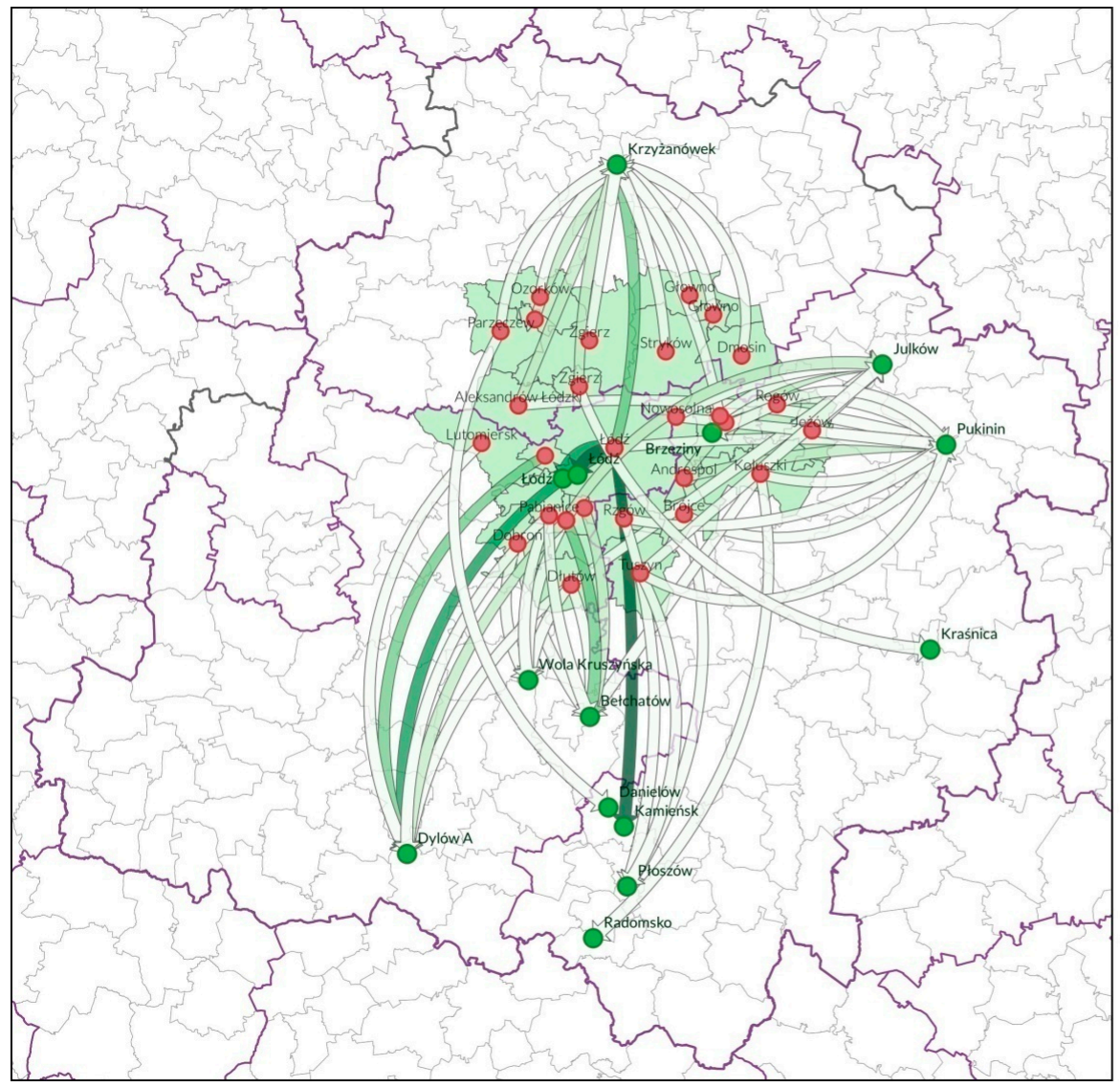

Mass of VFG waste [tonnes/year]

$$
\begin{array}{ll}
\Rightarrow & 11706-24191 \\
\Rightarrow & 6399-11706 \\
\Rightarrow & 1558-6399 \\
\Rightarrow & 577-1558 \\
\Rightarrow & 2-577
\end{array}
$$

\section{Łódź Metropolitan Area} Łódzkie voivodeship boudnary of Region of Waste Management(RGOK)

—_ boundary of voivodeship boundary of gmina

- waste management facility (destination)

- centroid of origin

Figure 6. Waste flows for 2016 generated in ŁOM. Source: authors' own elaboration. 
This portrayal of the division of the voivodeship into regions makes clear the logic of waste management being made subject to spatial planning, with the assumption of course being that things pay best where wastes are only transported over shorter distances. Wastes that cannot be utilised within the RGOK corresponding with the given gminas must then be dealt with elsewhere-as a consequence of infrastructural limitations, or else amendments to contracts concluded between local authorities and a firm taking delivery of wastes during a given calendar year. A situation of this kind can influence conclusions arising out of the analysis of flows in a given year, hence the need to accept that the $21 \%$ reflects a change in the recipient of wastes, even if it is not known whether that change was directed by the division into region or other premises and had a reverse direction (with wastes actually transported further). Derogation from the standards and rules in force for the spatial organisation of waste-management systems with simultaneous burdening of local authorities with that same obligation ensures that the division into regions and all rules associated with closed-cycling of wastes within a given voivodeship may go unheeded.

\subsection{Waste Management and Governance}

Each component part of the Łódź Metropolitan Area differs from others in terms of settlement structure and density of population. This implies problems with organisation of the waste-management system, given the collection systems of limited efficiency present in both rural and urban areas. In rural and urban-rural gminas the problem relates to proper organisation of the transport of small amounts or wastes, while in large cities it is more a matter of the possibility of collection of sorted waste being dependent on the relevant activity engaged in by inhabitants. A major problem here (to be noted across Poland) is people's low level of environmental awareness, as combined with poor management of the system in both logistical and spatial terms. Further factors implying problems within the Metropolitan Area are the inadequate number of installations available to process wastes, the lack of macroregional plans when it comes to diversification among recipients of wastes, the lack of installations with the necessary processing technology and the lack of solutions when it comes to any planning of closed-cycling. The area selected for study has to be seen as non-uniform, given that it includes one large city, as well as some more minor satellite towns plus rural areas. Differentiation in the geographical conditions is by no means helpful to the organisation of the waste-management system and does necessitate a multi-stranded approach.

The fact that local governments are responsible for the disposal of waste leaves this as one of the most important tasks of municipal management at present, while also constituting a key link between the local authority (efficient self-government) and inhabitants. A sensitive issue within this relationship-and the consequence of the local character of waste policy - is the fact that the collection of household waste has to be paid for via fees. Local authorities thus bear two kinds of political responsibility, on the hand discharging the tasks conferred by the legislator, while on the other remaining accountable for actions to people (including at the ballot box when local elections come along). It is in this context and against that background that processes of waste management selected for consideration at interviews needs to be considered. An in-depth analysis of the interviews in question pointed to regularities in the perception of major problems subject to different social, economic and political conditioning. However, there are relationships between problems (issues) that create a general picture of waste management.

In the course of the analysis of the interviews conducted, it is possible and necessary to address three equivalent issues, which also need to be the subject of conclusions regarding waste management. Depending on the stakeholder and its role in the waste-management process, the emphasis was on one or other of these issues, though most interviews in fact pertain to all three in one way or another, directly or indirectly. The three key issues were:

(1) Ecological awareness. This permeates all levels of the waste-management process and concerns decision-makers and producers of waste equally. What is involved here is noting the problem of human beings' influence on their environment, as well as the 
satisfaction of acting in such a way as to remain within the limits of the environment. Where the problem of waste management is concerned, the process of acquiring and enhancing knowledge is intended to reduce hazards arising from the generation of waste as a side effect of collective activity (the broad approach) or activity of the individual (the narrow approach). Ecological awareness is combined with a sense of social responsibility and civic co-management of the environment. In comparison with the countries of the "old union", Poland has citizens only manifesting these values at dramatically low levels.

(2) Legal status. The set of regulations in the field of waste management includes laws and regulations, with legal status being a manifestation of aspirations of the legislative authority and the executive at the state level, which sets the directions for actions and lays down expected effects in social space (ecological awareness) and physical space (the process of collecting and processing wastes). Legal status shapes the main mechanisms of waste management. For this reason, it is subject to the pressure of continuous assessment (approval or criticism) on the part of different circles in society, including stakeholders in change.

(3) Local-government policy. This represents a reaction to the existing legal status. Local authorities develop waste-management principles and are responsible for achieving outcomes vis-à-vis the collection and segregation processes. Local authorities and institutions are intermediary structures between residents (the local community), who evaluate activities and have needs and expectations and the state authorities, to which they direct comments on process imperfections and conditions, as well as postulating (consulting over) new legal solutions.

Additionally, PULL meetings proved that problems of greatest importance within the $Ł O M$ when it comes to waste management relate to social attitudes. These reflect a low level of pro-environmental awareness, old habits, disrespectfulness towards the landscape, but also a misunderstanding as to what the circular economy denotes. Residents do not perceive significant benefits in waste segregation, because either: (1) they do not perceive waste as a resource, or (2) they do not see economic benefits behind such an approach (as collection costs for segregated and unsegregated waste are very similar), or (3) they claim that they should receive recompense for selecting waste, even as they are being charged currently for engaging in it. All participants in PULL workshops thus agreed that the basic key flow in need of analysis under the REPAiR project for the Łódź Agglomeration involves municipal solid waste.

\subsection{Implementation of the GDSE}

The response to the issues raised above pointed to by stakeholders is a steering of the organisation of the waste-management system in the direction of a participatory model. It was also with such an aim in mind that the last element of the REPAiR Project research made use of the GDSE instrument. Table 1 below offers a simplified listing of the different stages described previously, as augmented by further results. However, it needs to be emphasised at the outset that the group of experts made a selecting of more than one Eco-Innovative Solution. The status quo as discussed in detail in the first part of this article was first presented in a Sankey diagram and map of the flow of biodegradablewastes generated within the Łódź Metropolitan Region. Following implementation of the EIS (as subject to discussion and modifications by experts in the course of the PULL exercise, the result of implementation of the strategy is obtained. A Sankey diagram is offered to present difference in magnitudes of flows between actors in the given area, as well as flows among new actors identified by the PULL experts. These solutions must gain simultaneous application, and this must be in line with rules devised by the legislator. 
Table 1. Main steps in the planning of flows of waste engaged in by groups of stakeholders and the research team via the GDSE application and during $n$ PULLs (simplified).

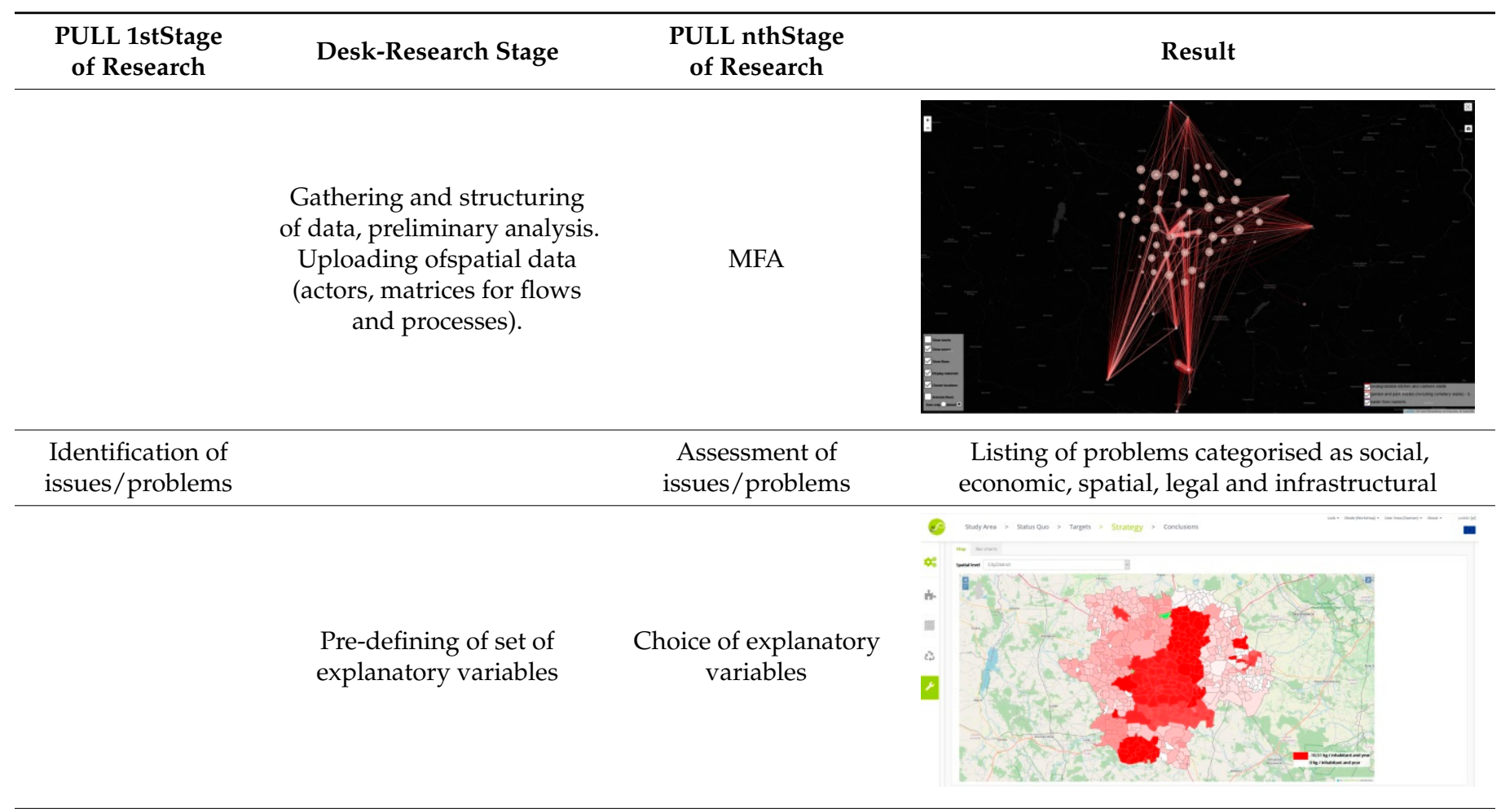

Gathering and structuring of data, preliminary analysis. Uploading ofspatial data and processes).
PULL nthStage

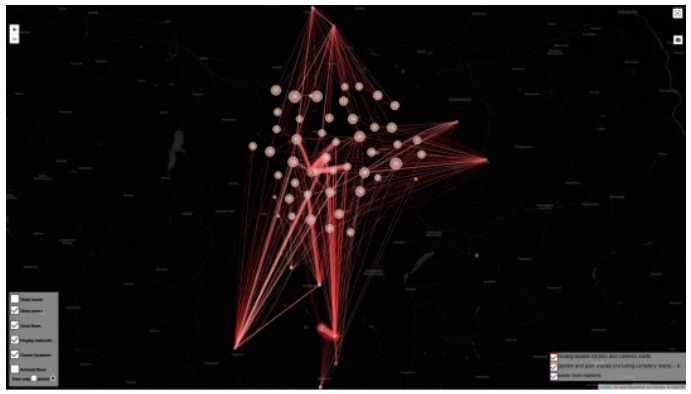

Listing of problems categorised as social, mic, spatial, legal and infrastructural
Programming of EIS

(Eco-Innovative

Solutions)
Selection and modification of EIS

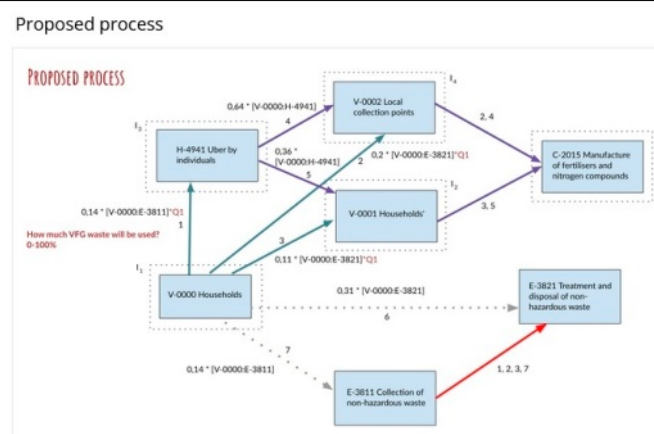

Identification of study area and focus area
Uploading of spatial data (on spatial units)
Delimitation of area of implementation

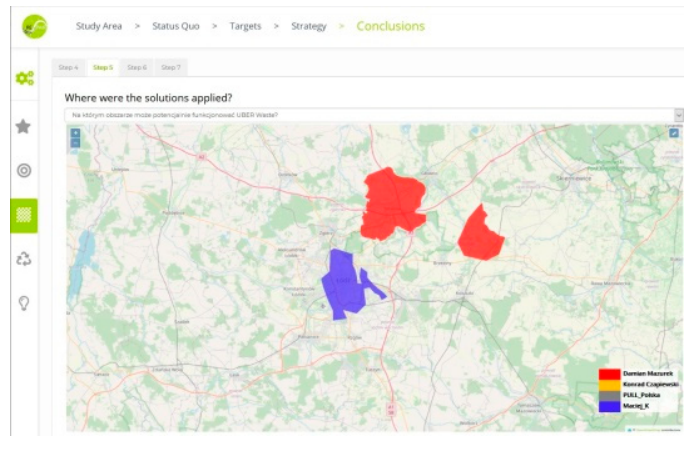


Table 1. Cont

\begin{tabular}{cccc}
\hline $\begin{array}{c}\text { PULL 1stStage } \\
\text { of Research }\end{array}$ & Desk-Research Stage & $\begin{array}{c}\text { PULL nthStage } \\
\text { of Research }\end{array}$ & Result \\
\hline $\begin{array}{c}\text { Preliminary } \\
\text { identification of } \\
\text { strategic goals }\end{array}$ & $\begin{array}{c}\text { Selection and ranking } \\
\text { of main and detailed } \\
\text { objectives. Choice of } \\
\text { stakeholders (actors) }\end{array}$ & Stas &
\end{tabular}

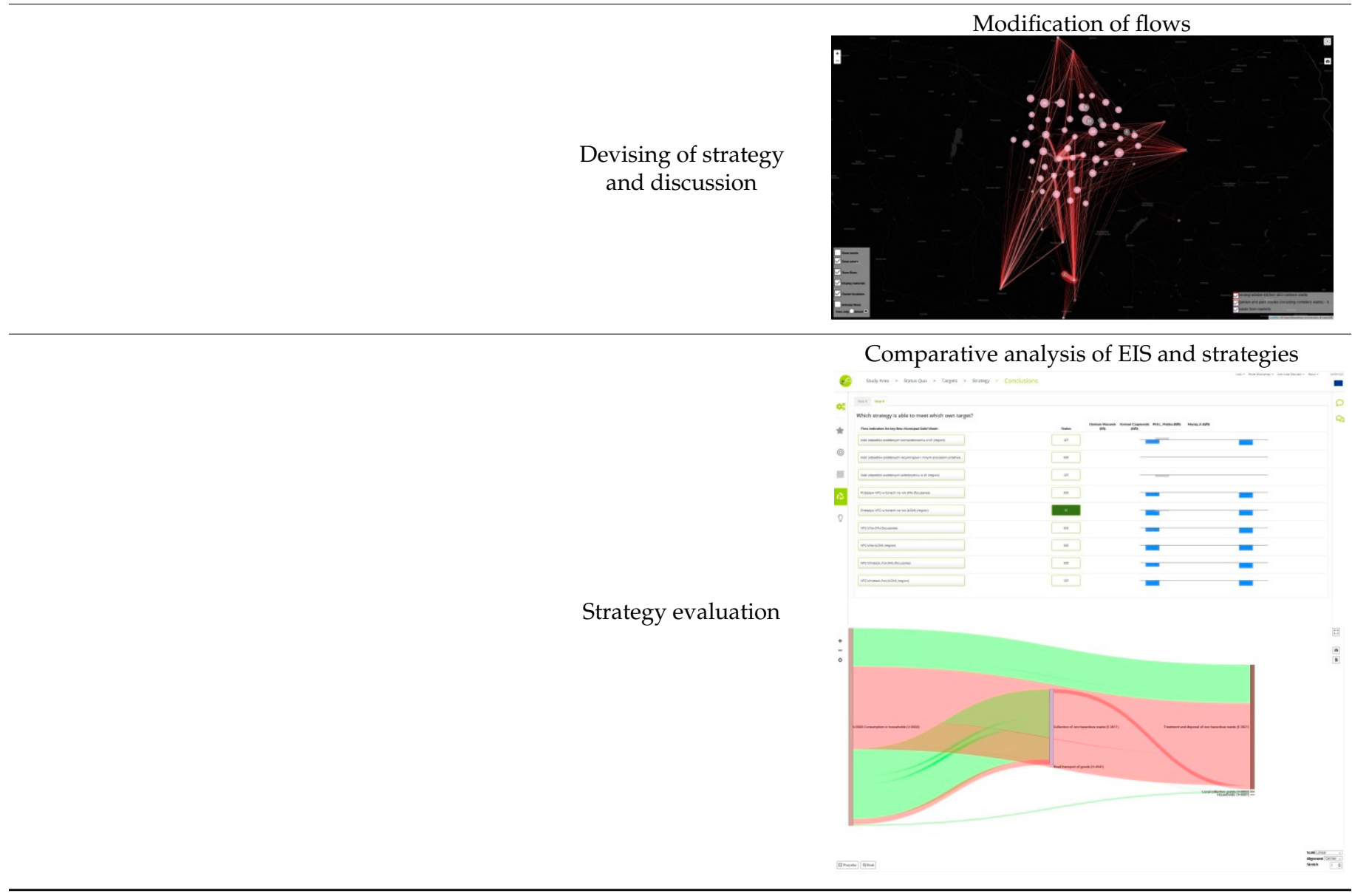

Source: authors' own elaboration-GDSE output.

The outcomes of work using a GDSE goes beyond a strategy, as a spatial model to simulate flows of wastes is also anticipated. The Sankey diagram (in Table 1) portrays the reduction of the said flows as compared with the status quo (Figure 6). Indeed, the group of experts had as their aim a reduction in amounts of biodegradable wastes going on to the market by way of a raising of inhabitants' awareness as to possibilities for biowastes to be utilised on site, with valuable compost made and with negative environmental influences reduced as the demand for transport is cut. Selection of indicators that measure flows in relation to population, area and over time allowed the area to be analyzed for further sustainability in the context of waste management. The next step was the amount of waste recycled according to specific processes-in this case composting, which increased by about $20 \%$ in one EIS, while in the other biodegradable waste went to the composting plant in a more efficient way thanks to a supply chain model based on greater market competition 
for suppliers. The different solutions show how important it is to choose the right waste management practices for the further sustainable development of waste treatment.

There was also an indication of social problems relating to a low level of environmental awareness among inhabitants, and-in the view of the experts-this needs to be made good through education as to the economic benefits accruing from proper sorting of wastes, as well as differentiated opportunities for them to be processed thanks to production technologies. By implementing into strategies solutions that are based on the use of existing or emerging infrastructure for the processing of biodegradable wastes (not least in the production of biofuels) it is possible to direct some of the wastes to new locations.

In reality, the GDSE application is a set of tools by which to create strategies for flowsof wastes, and to simulate the solutions experts arrive at. This process takes place by way of participation and takes account of the interests of different decision-making groups who are taking part. This principle is illustrated by the schematic representation below, which presents the key elements of GDSE-i.e., the identification and ranking of objectives of a strategy, as well as the result thereof, which is presented in the form of a set of indicators selected (by experts) to appraise the strategy in question. The results presented in Table 1 and Figure 7 are examples of participatory management in the wastes economy in an area with identified problems. By linking expert analyses carried out by members of scientific circles with PULL, and by implementing GDSE as well, it becomes possible to fill in gaps in the process by which waste management is planned, primarily by local authorities as it is their responsibility.

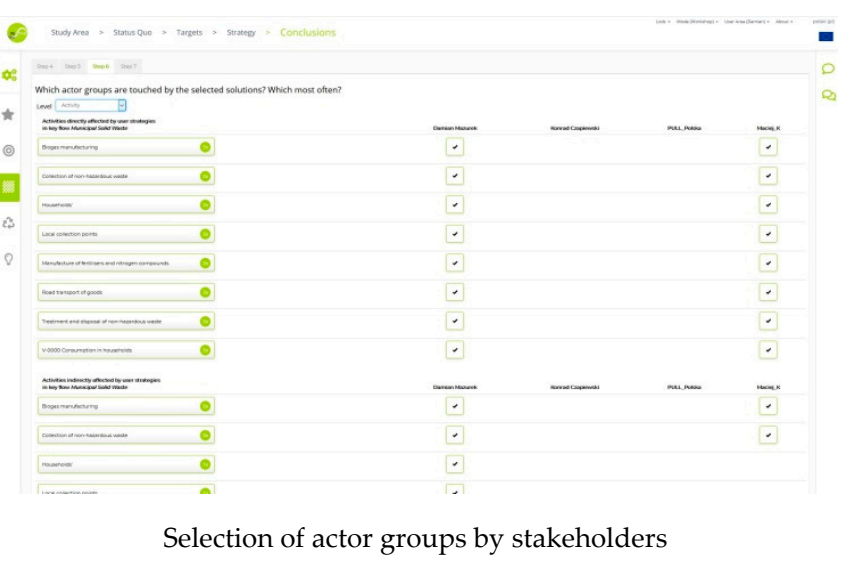

Figure 7. The participatory nature of the strategic planning and governance of waste flows in the GDSE.Source: authors' own elaboration-GDSE output, PULL results.

Large amounts of wastes pass to the region's several largest installations, as MFA, PULLand the visualisation of flows by GDSE all make clear-while there is a wide range of recipients among towns and rural areas. This attests to the existence of several key issues.Łódź voivodeship is witnessing a monopolising of the market for the collection of municipal wastes, with the result that prices are rising and there is a developing lack of trust along the chain between inhabitants, local authorities and entrepreneurs as recipients of wastes. These results are confirmed by more in-depth research within the framework of PULLworkshops and interviews. Furthermore, to be seen in some of the gminas making up the Łódź Metropolitan Area are changes probably made in 2016 in relation to the choice of firms collecting and managing wastes. These changes may also reflect infrastructural limitations characterising the entity that has been the recipient up to now. An important postulate here involves an enhanced role for inhabitants in the long-term planning process. Among key objectives in the contextof the development of the circular economy are an increased significance of composting on private premises, increased processing capacity at installations utilising biowastes (i.a., in producing biofuels and biogas), a reduction in the amounts of wastes being dumped at landfills and a lowering of the fees for collecting 
and receiving wastes. As PULL results and the strategic planning under GDSEmake clear, achievement of the above objectives works to lower the total mass of wastes flowing, while it gives rise to an increased number of transport links. This is probably a reflection of the transitional stage we are in when it comes to the development of entrepreneurship and innovation in waste management. This is nevertheless a stage from which Poland has been emerging steadily.

However, the early nature of the stage reached in Poland when it comes to developing eco-innovation gains confirmation in the research, as does the limited level of public involvement in pro-environmental initiatives [62]. While a diversified market characterising recipients allows relatively low prices to be maintained, these should depend more and more on implemented innovation allowing wastes to be used as raw materials. However, biowaste processing is characterised by a high financial threshold for entry on to the market, even as it can supply measurable benefits to all groups of stakeholders [40].

\section{Discussion}

The attempt to determine the correctness of the assessment of waste-management system as it operates currently proves very difficult, due to the relative brevity of the period in operation of the new rules (i.e., the ones transferring responsibility to local governments from 2013 on). The coming years will be decisive ones where the stabilisation of the waste collection and treatment system is concerned. Major responsibility for this lies with the legislative and executive authorities at the highest, state level, which will need over a short time to verify the instruments by which the outcome of waste being used to produce new goods is achieved. An important role in this respect should be played by associations of local authorities, which articulate the need for the modification and modernisation of approaches to waste management, including as regards the development of new legal regulations. However, the achievement of success in the functioning of circular-economy rules will depend to the greatest extent on both urban and rural ecological awareness being strengthened.

However, the legislator's imposition of an obligation that local authorities should engage in waste management puts no restrictions on the streamlining of the system. The example of the Łódź Metropolitan Area shows that there is a place for social dialogue devoted to the need for change arising for different reasons among different groups of stakeholders. As early as 2004, Carmin and Vandeveer indicated that the CEECs faced significant constraints when it came to pro-environmental policies, even as the authors were able to emphasise the clear importance of non-state actors, and the role played by cooperation between Member States and Candidate Countries for EU accession as regards the development of legal and legislative instruments [63].

Furthermore, this example brings to light the problem of lack of consultation between local authorities, entrepreneurs and inhabitants. All three groups of stakeholders should draw benefit from a system of waste management that operates efficiently. A failure on the part of one group to understand the problems and issues the others have acts to put a brake on activity seeking to raise the quality of waste collection and management services. The foundation overall lies in the rational management of such resources as wastes, infrastructure, the environment and space. To some extent at least, the methods presented in this article can provide answers for these dilemmas, given the way they bring the desired effects when it comes to both social dialogue and the implementation of GeoDesign. There is also some kind of antidote offered to the not-very-optimistic research results presented by Walczak et al. [62], with the difference being that the main interest in eco-innovation and research in this context is being shown by local government.

The problem of the non-uniformity of the study area that is the Łódź Metropolitan Area does not have much ultimate significance where many groups of stakeholders representing different institutions and areas work to devise a strategy for an area of this type. It needs to be emphasised that solutions of the EIS kind will operate quite differently in rural areas as opposed to in cities. However, the implementation of many EIS in areas 
defined precisely by experts, with simultaneous discussion on the part of inhabitants, localauthority representatives, spatial-planning experts and representatives of the private sector working in waste management, all ensures that a strategy drawn up will be comprehensive, correct from the substantive point of view and planned sensibly. In addition, it should be noted that each group of stakeholders participates in the process of strategy consultation representing their interests, which means that there is an exchange of views and direct discussion between representatives of legislative bodies and electorate-entrepreneurs and residents. Such a model influences both the building of relations between these groups and trust, as a compromise is built at the meeting point of several theoretically opposing interests.

Model conceptualisations of this type of activity relating to management and planning are as presented in the diagram below (Figure 8). The management model developed in our research is based around the participatory nature of a research process run in a problem area [6], and it also takes account of the participation of both the public and other groups of stakeholders at more than one stage of the planning process, as has been noted by Hung et al. [26] and Steintz [6], among others. The results are measurable positive influences of economic, social and environmental nature, while beneficiaries are these same groups of stakeholders that play a part in the management process-inhabitants included.

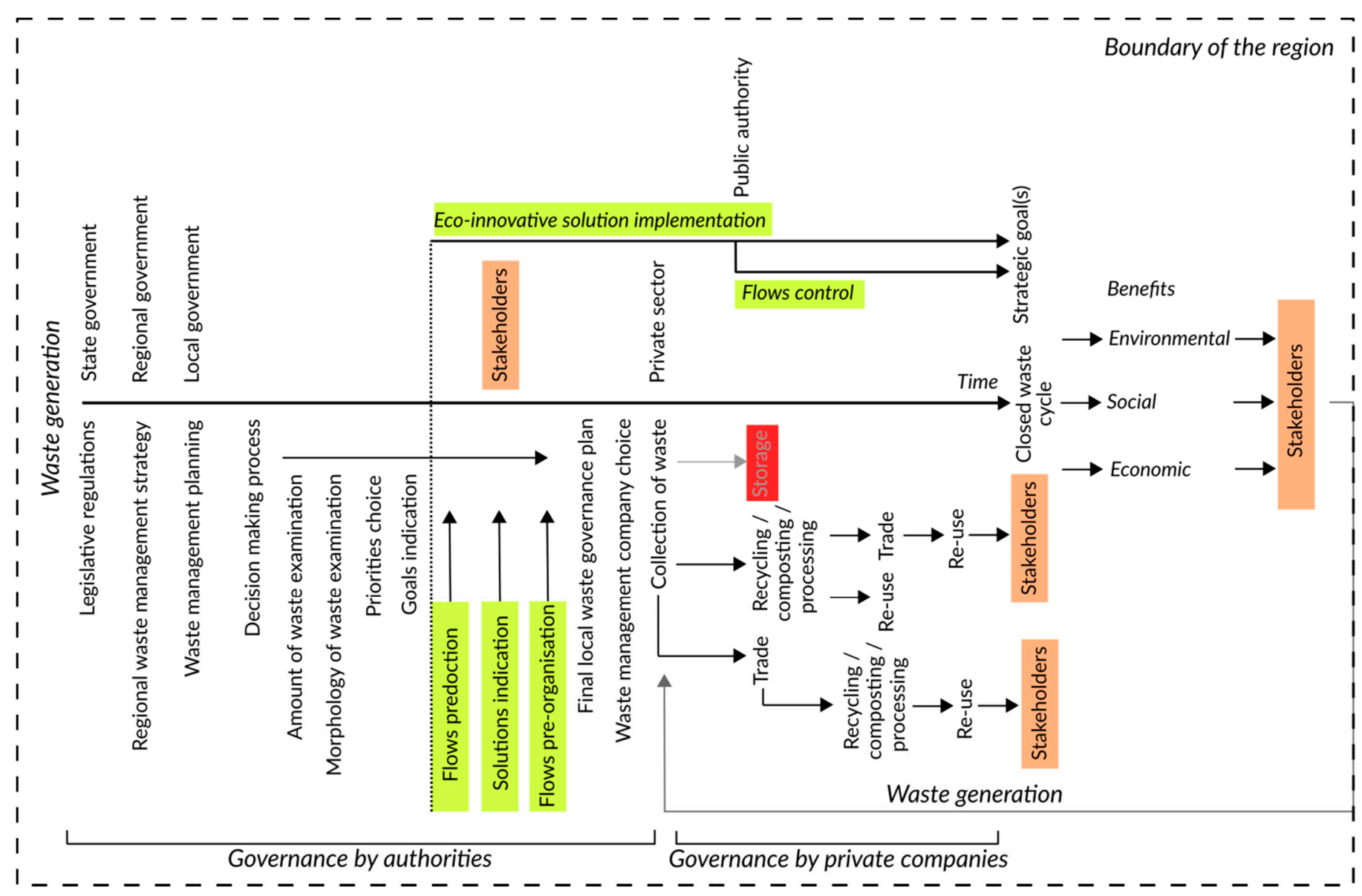

Figure 8. The model of governance in the context of waste flows and benefits-EIS-REPAiR PULL-result implementation. Source: authors' own elaboration.

\section{Conclusions}

The results of our study encourage reflection on the development of qualitative and quantitative methods, in the context of their synergies being used in waste management, as well as on the ways in which benefits, and new knowledge may be translated into practice. 
The methods in question were intended to address the problem of multidimensionality of waste management, and lead to the development of a synthetic management model. While it proves very difficult to take account of all the elements in the system, the main assumption here revolved around the social dimension of the study, with the aim being for the problem posed by stakeholders to be resolved.

The presented example is treated by the authors as a prelude to further refinement of the methods used, even as it is borne in mind what difficulties are involved in implementing the concept into circular-economy planning-from problem identification, through analysis of the entire flow chain, to strategy development. In addition to elements of a system of waste management that can be measured objectively, there are independent factors that define the system, i.e., the human factor and the legislative-administrative factor, which sometimes fails to take account of certain important issues. For example, the legislator may assume that the level of recycling to be achieved by all units of local-government administration (in Poland, gminas) will be set at, say, $70 \%$, but that provision may not be in line with the actual conditions at local level-the availability of waste-management infrastructure, the local market served bywaste-processing entrepreneurs, the variability of costs depending on that market and the decisions made by local authorities, and, finally, opposition of one kind or another relating to public opinion.

This last factor proves problematic for several reasons. First, inhabitants may be against the segregation rules a government or local authority introduces; second, the need to care for the environment must inevitably relate to a given person's own hierarchy of needs; third, the encouragement of segregation, composting or reduction of waste generated may take different forms, with a uniform method in any case not achieving the same effect always and everywhere. The model applied in extending financial incentives seems important in this case and does not in turn reflect well upon environmental awareness. On the one hand, it may reflect rapid economic development in Poland and a desire on the part of society for enrichment in a period of prosperity. On the other hand, a lack of knowledge may not result from lack of education or even people's different hierarchies of needs, but rather from the poor accessibility of knowledge regarding the benefits of a pro-environmental attitude. In turn, benefits accruing may be local, i.e., directly perceivable by inhabitants (inair in a better condition, access to clean and cheap energy), or global, meaning that it links up with changes in the economy of a region or country, or with climate and environmental changes arising out of a diffusion of local benefits.

The research presented points clearly to a problem with lack of knowledge on possibilities (methods and technologies) for waste reuse, as well as future benefits accruing where eco-innovative solutions are implemented. However, insight as regards residents ${ }^{\prime}$ ecological awareness demands additional sociological analysis of an in-depth nature, even as the research procedure we have implemented is able to demonstrate the advantages of participatory methods using the latest technological solutions, as well as the feedback effect of knowledge shared between stakeholders-i.e., planners, officials or residents defining a problem on the one hand and experts (i.e., representatives of science and business) on the other. Ultimately, the product of the strategy developed jointly by the two groups of actors reaches stakeholders in the form of solutions ready for implementation, and in turn expected to be of environmental, economic and social benefit.

The authors have here sought to answer nagging questions which are many in number, if relating largely to the scale of local effects, even though relevant macro-scale evolution would be both possible and desirable. That fact ensures the importance ofa continuation of the quantitative and qualitative research our literature review cites. Integration of the researchers' achievements in the development of decision and location models gains presentation here as a schematic result of the waste-management process, as arising out of a triangulation of quantitative, qualitative and spatial methods. It should thus be emphasized how analysis was exemplified by an area of diverse geographical characteristics, given the presence of a single large city, suburban areas, urban areas of medium and small size and rural areas. Such are the specifics in this case that the universality of the results presented 
might conceivably be questioned. It is anyway necessary for further steps to be taken to verify the variables adopted and improve the set of methodological tools, hence the authors' perceived need that further research of an evaluative nature be carried out.

Author Contributions: Conceptualization, D.M. and K.C.; methodology, D.M. and K.C.; software, D.M.; validation, D.M. and K.C.; formal analysis, D.M. and K.C.; investigation, D.M. and K.C.; resources, D.M. and K.C.; data curation, D.M. and K.C.; writing-original draft preparation, D.M. and K.C.; writing-review and editing, D.M. and K.C.; visualization, D.M.; supervision, D.M. and K.C.; project administration, K.C.; funding acquisition, K.C. Both authors have read and agreed to the published version of the manuscript.

Funding: This article reflects only the author's view. The Commission is not responsible for any use that may be made of the information it contains. This project has received funding from the European Union's Horizon 2020 research and innovation programme under grant agreement No 688920.

Institutional Review Board Statement: Not applicable.

Informed Consent Statement: Not applicable.

Data Availability Statement: http://h2020repair.eu/, access: 20 April 2021

Acknowledgments: The authors would like to thank all participants in the REPAiR project for the scientific discussions that made it possible to realize the research in the form finally presented.

Conflicts of Interest: The authors declare no conflict of interest. The funders had no role in the design of the study; in the collection, analyses or interpretation of data; in the writing of the manuscript, or in the decision to publish the results.

\section{References}

1. Ghiani, G.; Laganà, D.; Manni, E.; Musmanno, R.; Vvigo, D. Operations research in solid waste management: A survey of strategic and tactical issues. Comput. Oper. Res. 2014, 44, 22-32. [CrossRef]

2. Passarini, F.; Vassura, I.; Monti, F.; Morselli, L.; Villani, B. Indicators of waste management efficiency related to different territorial conditions. Waste Manag. 2011, 31, 785-792. [CrossRef]

3. Guerrero, L.A.; Maas, G.; Hogland, W. Solid waste management challenges for cities in developing countries. Waste Manag. 2013, 33, 220-232. [CrossRef] [PubMed]

4. Śleszyński, P.; Stępniak, M.; Mazurek, D. Oszacowanie skutków presji inwestycyjnej i nadpodaży gruntów budowlanych w strefie podmiejskiej Warszawy na przykładzie gmin pasma zachodniego. Przegląd Geogr. 2018, 90, 209-240. [CrossRef]

5. Czapiewski, K.; Mazurek, D.; Traczyk, A.; Wójcik, M. Waste Material Flow Analysis in the Łódź Metropolitan Area. Eur. Spat. Res. Policy 2020, 27, 95-114. [CrossRef]

6. Steinitz, C. A Framework for Geodesign: Changing Geography by Design; Esri: Redlands, CA, USA, 2012.

7. Lacko, R.; Hajduová, Z.; Zawada, M. The Efficiency of Circular Economies: A Comparison of Visegrád Group Countries. Energies 2021, 14, 1680. [CrossRef]

8. Badran, M.F.; El-Haggar, S.M. Optimization of municipal solid waste management in Port Said—Egypt. Waste Manag. 2006, 26, 534-545. [CrossRef]

9. Ghose, M.K.; Dikshit, A.K.; Sharma, S.K. A GIS based transportation model for solid waste disposal—A case study on Asansol municipality. Waste Manag. 2006, 26, 1287-1293. [CrossRef]

10. Malinowski, M.; Woźniak, A. Problem optymalizacji logistycznych parametrów transportu odpadów komunalnych w aspekcie strategii ekofirmy. Infrastrukt. Ekol. Teren. Wiejskich 2011, 10, 107-119.

11. Fiorucci, P.; Miniciardi, R.; Robba, M.; Sacile, R. Solid waste management in Urban areas: Development and application of a decision support system. Resour. Conserv. Recycl. 2003, 37, 301-328. [CrossRef]

12. Wota, A.; Woźniak, A. Metodyka wyboru lokalizacji składowisk odpadów komunalnych. Infrastrukt. Ekol. Teren. Wiej. 2008, 8 , 143-156.

13. Zemanek, J.; Malinowski, M.; Woźniak, A. Opracowanie zasad wyboru lokalizacji “Centrum Recyklingu” z wykorzystanie manalizy wielokryterialnej GIS. Infrastrukt. Ekol. Teren. Wiej. 2009, 5, 219-230.

14. Banias, G.; Achillas, C.H.; Vlachokostas, C.H.; Moussiopoulos, N.; Tarsenis, S. Assessing multiple criteria for the optima location of a construction and demolition waste management facility. Build. Environ. 2010, 45, 2317-2326. [CrossRef]

15. Noche, B.; Rhoma, F.A.; Chinakupt, T.; Jawale, M. Optimization model for solid waste management system network design case study. In Proceedings of the 2nd International Conference on Computer and Automation Engineering (ICCAE), Singapore, 26-28 February 2010.

16. Kolendo, M.; Kolendo, Ł. Model decyzyjny GIS we wspomaganiu wyboru lokalizacji składowiska odpadów komunalnych (na przykładzie części powiatu białostockiego). Ekon. Sr. 2013, 2, 7-13. 
17. Malinowski, M.; Krakowiak-Bal, A.; Sikora, J.; Woźniak, A. Ilości generowanych odpadów komunalnych w aspekcie typów gospodarczych gmin województwa małopolskiego. Infrastrukt.Ekol. Teren. Wiej. 2009, 9, 181-191.

18. Malinowski, M.; Krakowiak-Bal, A.; Sikora, J.; Woźniak, A. Wykorzystanie analizy przestrzennej GIS do wyznaczania wskaźników nagromadzenia odpadów w zależności od liczby mieszkańców i gęstości zaludnienia. Infrastrukt. Ekol. Teren. Wiej. 2009, 9, 193-205.

19. Kamiński, W.; Szyrmer, J. Środowisko przyrodnicze w wybranych teoriach i modelach równowagii wzrostu gospodarczego. Pr. Geogr. 1981, 139, 89-119.

20. Binder, C.R.; Mosler, H.-J. Waste-Resource flows of short live foods in households of Santiago de Cuba. Resour. Conserv. Recycl. 2007, 51, 265-283. [CrossRef]

21. Plewa, M.; Giel, R.; Klimek, M. Analiza porównawcza gospodarki odpadami w Polsce i innych krajach europejskich. Logistyka 2014, 6, 8748-8758.

22. Denafas, G.; Ruzgas, T.; Martuzevi` cius, D.; Shmarin, S.; Hoffmann, M.; Mykhaylenko, V.; Ogorodnik, S.; Romanov, M.; Neguliaeva, E.; Chusov, A.; et al. Seasonal variation of municipal solid waste generation and composition in four East European cities. Resour. Conserv. Recycl. 2014, 89, 22-30. [CrossRef]

23. Pires, A.; Martinho, G.; Chang, N.-B. Solid waste management in European countries: A review of systems analysis techniques. J. Environ. Manag. 2011, 92, 1033-1050. [CrossRef]

24. Kukuła, K. Regionalne zróżnicowanie stopnia zanieczyszczenia środowiska w Polsce a gospodarka odpadami. Przedsiębiorczość $i$ Zarzadzanie 2014, 15, 183-198.

25. Hui, Y.; Li'ao, W.; Fenwei, S.; Gang, H. Urban solid waste management in Chongqing: Challenges and opportunities. Waste Manag. 2006, 26, 1052-1062. [CrossRef]

26. Hung, M.-L.; Ma, H.; Yang, W.-F. A novel sustainable decision making model for municipal solid waste management. Waste Manag. 2007, 27, 209-219. [CrossRef]

27. Abeliotis, K.; Karaiskou, K.; Togia, A.; Lasaridi, K. Decision support systems in solid waste management: A case study at the national and local level in Greece. Glob. NEST J. 2009, 11, 117-126.

28. Nahman, A.; Godfrey, L. Economic instruments for solid waste management in South Africa: Opportunities and constraints. Resour. Conserv. Recycl. 2010, 54, 521-531. [CrossRef]

29. Demirbas, A. Waste management, waste resource facilities and waste conversion processes. Energy Convers. Manag. 2011, 52, 1280-1287. [CrossRef]

30. Nema, A.K.; Gupta, S.K. Optimization of regional hazardous waste management systems: An improved formulation. Waste Manag. 1999, 19, 441-451. [CrossRef]

31. Contreras, F.; Hanaki, K.; Aramaki, T.; Connors, S. Application of analytical hierarchy process to analyze stakeholders preferences for municipal solid waste management plans, Boston, USA. Resour. Conserv. Recycl. 2008, 52, 979-991. [CrossRef]

32. Marginho, A.; Didelet, F.; Semiao, V. Municipal solid waste disposal in Portugal. Waste Manag. 2006, 26, 1477-1489.

33. Okot-Okumu, J.; Nyenje, R. Municipal solid waste management under decentralization in Uganda. Habitat Int. 2011, 35, 537-543. [CrossRef]

34. Beccali, G.; Cellura, M.; Mistretta, M. Managing Municipal Solid Waste. LCA Case Stud. 2001, 4, 243-249. [CrossRef]

35. Antonopoulos, I.-S.; Karagianiidis, A.; Tsatsarelis, T.; Perkoulidis, G. Applying waste management scenarios in the Peloponnese region in Greece: A critical analysis in the Frome of life cycle assessment. Environ. Sci. Pollut. Res. 2013, 20, 2499-2511. [CrossRef]

36. Nakamura, S.; Kondo, Y. Input-Output Analysis of Waste Management. J. Ind. Ecol. 2002, 6, 39-63. [CrossRef]

37. Eriksson, O.; Carlsson Reich, M.; Frostell, B.; Bjőrklund, A.; Assefa, G.; Sundqvist, J.-O.; Granath, J.; Baky, A.; Thyselius, L. Municipal solid waste management from a systems perspective. J. Clean. Prod. 2005, 13, 241-252. [CrossRef]

38. Ionescu, G.; Rada, E.C.; Ragazzi, M.; Ma $`$ rculescu, C.; Badea, A.; Apostol, T. Integrated municipal solid waste scenario model using advanced pretreatment and waste to energy processes. Energy Convers. Manag. 2013, 76, 1083-1092. [CrossRef]

39. Antonopoulos, I.-S.; Perkoulidis, G.; Logothetis, D.; Karkanias, C. Ranking municipal solid waste treatment alternatives considering sustainability criteria using the analytical hierarchical process tool. Resour. Conserv. Recycl. 2014, 86, 149-159. [CrossRef]

40. Seruga, P. The Municipal Solid Waste Management System with Anaerobic Digestion. Energies 2021, 14, 2067. [CrossRef]

41. Morrissey, A.J.; Browne, J. Waste management models and their application to sustainable waste management. Waste Manag. 2004, 24, 297-308. [CrossRef]

42. Dyson, B.; Chang, N.-B. Forecasting municipal solid waste generation in a fast-growing urban region with system dynamics modeling. Waste Manag. 2005, 25, 669-679. [CrossRef]

43. Mazurek, D. Uwarunkowania funkcjonowania systemu gospodarki odpadami w Polsce-Czynniki społeczne, przestrzennei infrastrukturalne. Czas. Geogr. 2019, 90, 111-130.

44. Cała, C. Koncepcja gospodarki bezodpadowej w polityce ochrony środowiska naturalnego. Biul. Inf. 1985, 49, 53.

45. Tundys, B. Zielonyłańcuchdostaw w gospodarce o okrężnymobiegu—Założenia, relacje, implikacje. Pr. Nauk. Unizw. Ekon. Wrocławiu 2015, 383, 288-301.

46. Szyja, P. Istota, zakres i praktyka kształtowania gospodarki okrężnej. Pr. Nauk. Uniw. Ekon. Wroctawiu 2016, 453, 132-141.

47. Pieńkowski, D.; Kośmicki, E. Funkcja produkcji gospodarki zamkniętego obiegu. Ekon. Sr. 2016, 2, 10-22. 
48. Shekdar, A.V. Sustainable solid waste management: An integrated approach for Asian countries. Waste Manag. 2009, 29, 1438-1448. [CrossRef]

49. Smol, M.; Marcinek, P.; Koda, E. Drivers and Barriers for a Circular Economy (CE) Implementation in Poland-A Case Study of Raw Materials Recovery Sector. Energies 2021, 14, 2219. [CrossRef]

50. Wastes Act of December 12, 2012; Dz. U: Łódź, Poland, 2013; Volume 21. (In Polish)

51. Lipińska, D. Gospodarka Odpadowa I Wodno-Ściekowa; Uniwersytet Łódzki: Łódź, Poland, 2016; pp. 15-61. [CrossRef]

52. Łuniewski, S. Gospodarka Odpadami na Obszarach Przyrodniczo Cennych w Polsce. Wybrane Aspekty. Ekon. Sr. 2015, 3, $145-153$.

53. Dyrektywa Parlamentu Europejskiego I Rady 2008/98/WE Z Dnia 19 Listopada 2008 R. W Sprawie Odpadów Oraz Uchylająca Niektóre Dyrektywy (Tekst Majacy Znaczenie Dla EOG). Available online: https:/ / eur-lex.europa.eu/legal-content/PL/TXT/ HTML/?uri=CELEX:32008L0098\&from=EN (accessed on 30 May 2019).

54. Ocena Funkcjonowania Obecnego Systemu Gospodarki Odpadami Komunalnymi w Polsce. Informacja Polskiej Izby Gospodarki Odpadami Posiedzenie Komisji Ochrony Środowiska, Zasobów Naturalnych i Leśnictwa. 2007. Available online: http:/ / orka. sejm.gov.pl/WydBAS.nsf/0/3112c40f1fbf99dfc1257290005079e2/\$FILE/System\%20gospodarki\%20odpadami.pdf (accessed on 30 May 2019).

55. Styś, T.; Foks, R. Rynek gospodarowania odpadami komunalnymi w Polsce. Perspektywa 2014, $2030,71$.

56. Toruński, J. Zarządzanie gospodarką odpadami komunalnymi w Polsce. Zesz. Nauk. Uniwesytetu Przyr. Humanist. Siedlcach. Ser. Adm. Zarzadzanie 2010, 14, 31-47.

57. Kulczycka, J.; Kowalski, Z. Principles of municipal waste management in Poland and selected regions of Europe. Pol. J. Chem. Technol. 2008, 28-33. [CrossRef]

58. Kołsut, B. Inter-Municipal Cooperation in Waste Management: The Case of Poland. Quaest. Geogr. 2016, 91-104. [CrossRef]

59. Ingaldi, M.; Jursova, S. Economy and Possibilities of Waste Utilization in Poland. In Proceedings of the METAL 2013 22nd International Conference on Metallurgy and Materials, Brno, Czech Republic, 15-17 May 2013; TANGER Ltd.: Ostrava, Czech Republic, 2013.

60. Antczak, E. Municipal waste in Poland: Analysis of the spatial dimensions of determinants using geographically weighted regression. Eur. Spat. Res. Policy 2016, 177-197. [CrossRef]

61. Czapiewski, K.; Bański, J.; Wójcik, M.; Mazurek, D.; Traczyk, A.; Bodor, A.; Grünhut, Z.D. 3.5 Process model for the follow-up cases: Łódź. REPAiR Proj. IGSO PAS 2018.

62. Walczak, D.; Dziawgo, L.; Dziawgo, D.; Buszko, M.; Pawłowski, J.; Żołądkiewicz-Kuzioła, A.; Krupa, D. Attitudes and Behaviors Regarding Environmental Protection in the Financial Decisions of Individual Consumers. Energies 2021, 14, 1934. [CrossRef]

63. Carmin, J.; Vandeveer, S.D. Enlarging EU Environments: Central and Eastern Europe from Transition to Accession. Environ. Politics 2004, 13, 3-24. [CrossRef] 